University of Nebraska - Lincoln

DigitalCommons@University of Nebraska - Lincoln

Faculty Publications: Department of Teaching, Department of Teaching, Learning and Teacher Learning and Teacher Education

Education

October 2005

\title{
Systemic High School Reform in Two States: The Serendipity of State-Level Action
}

\author{
Edmund T. Hamann \\ University of Nebraska - Lincoln, ehamann2@unl.edu
}

Follow this and additional works at: https://digitalcommons.unl.edu/teachlearnfacpub

Part of the Teacher Education and Professional Development Commons

Hamann, Edmund T., "Systemic High School Reform in Two States: The Serendipity of State-Level Action" (2005). Faculty Publications: Department of Teaching, Learning and Teacher Education. 56.

https://digitalcommons.unl.edu/teachlearnfacpub/56

This Article is brought to you for free and open access by the Department of Teaching, Learning and Teacher Education at DigitalCommons@University of Nebraska - Lincoln. It has been accepted for inclusion in Faculty Publications: Department of Teaching, Learning and Teacher Education by an authorized administrator of DigitalCommons@University of Nebraska - Lincoln. 


\section{Systemic High School Reform in Two States: The Serendipity of State-Level Action}

\author{
Edmund T. Hamann \\ University of Nebraska-Lincoln
}

Maine and Vermont have been national leaders in state-level coordination of high school reform. Both recently developed almost interchangeable, new, voluntary, statewide frameworks that describe multiple ways high schools should change. Both frameworksPromising Futures (Maine Commission on Secondary Education 1998) and High Schools on the Move (Vermont High School Task Force 2001)—were published in book form and include extensive bibliographies grounding their claims that they are research based. Both frameworks recommend principles and practices for improving high schools for all students. Both frameworks were drafted primarily by leading local educators with only modest support from experts based beyond the state's boundaries. Despite these similarities, the strategies for implementing these frameworks in each state have varied and, because of this, the two frameworks' prospects of having enduring favorable impact also appear to vary. Using historical and ethnographic methods to conduct two policy implementation case studies, this paper describes both framework's development and then focuses on early implementation. Together the cases illustrate how more than an adequate whole-school reform framework is necessary to raise the prospect of enduring high school improvement. They also illustrate the potential of anthropological inquiry to the study of educational policy development and implementation.

\section{The Challenge of Scale-Up and the Prospective Role of SEAs in High School Reform}

If, as current rhetoric promises, we really are to educate all students to a high standard, then it
* This article is based on work completed for the Education Alliance at Brown University and was supported by the Institute of Education Sciences (IES), U.S. Department of Education, under Contract Numbers ED-01-CO-0010 and RJ96005401. Any opinions, findings, and conclusions or recommendations expressed in this material are those of the author and do not necessarily reflect the views of IES, the U.S. Department of Education, any other agency of the U.S. Government, or The Education Alliance. The author would like to thank Hugh Mehan and John Clarke for their suggestions regarding earlier versions of this paper. 
follows that all schools within a jurisdiction need to work well with the students they enroll. It further follows that if some schools are faring better than others then there will be a pressure to transfer ideas and practices from the schools faring better to those that are struggling. It is roughly from this logic that, at the dawning of the 21st century, we have come to the current historical moment wherein through private efforts like the New American Schools (NAS) project (Berends et al. 2001), federal ones (like the Comprehensive School Reform program), and the entrepreneurial efforts of education reformers like Ted Sizer, Bob Slavin, and James Comer, less successful schools are facing incentives and pressure to import ideas developed elsewhere. We have thus also come to an historical moment where concerns about scalingup successful education models are central concerns (Coburn 2003; Datnow, et al. 2002, Murphy and Datnow 2003) and where entities, like state education agencies (SEAs), that can support scale-up are worthy of scrutiny/consideration.

The quest for viable whole-school change models at the high school level is particularly acute, as for 20 years, if not longer, high schools have been loci of substantial reform-oriented attention (e.g., Boyer 1983; Lightfoot 1983; Sizer 1984, 1992, 1996; Lee 2001). However, despite that attention, high schools have not systematically and enduringly became more successful learning environments for most of their students. The point here is not to sweepingly label high schools as "good" or "bad," but rather to suggest that they have not in aggregate gotten better (as evidenced for example by the flatness of in high school students NAEP achievement scores [Campbell et al. 2000]). The explanations for this relative failure are no doubt multiple, but two key and intertwined explanations are (1) the traditional resistance of high schools to reform (Lee 2001, McQuillan 1998, Muncey and McQuillan 1996, Sarason 1990) and (2) the typical reliance on key personnel for those reforms that do succeed (Fink 2000). In other words high schools are hard to change, but, even when they are purposefully changed, too often the change is temporary, disappearing when a teacher retires, a principal moves, or a superintendent is fired.
Thus, even as the impetus for disseminating effective models and practices is increasing, education research is also demonstrating how difficult it is for individual schools to sustain innovation and success. As Fink (2000) notes in his compelling 30-year case study of a Canadian secondary school, innovative schools are buffeted by the same social forces (policy requirements, budget cycles, precedent, and expectations) that make conventional schools conventional. Thus it requires ongoing extra energy expenditures to remain in disequilibrium with the typical (Clarke 2003). Given this dynamic, one compelling way to sustain innovation and excellence is to have an improving school not get substantially out of equilibrium with other schools. This sounds like an oxymoron (if the goal is sustained improvement) until one considers the prospect of changing the equilibrium-i.e., moving the norm by having school improvement occur concurrently with systemic change.

Lusi (1997, p. 6) defines two essential components of viable systemic school reform:

- It "strives to reform the education system as a system" (italics in original). That means education systems' component policies need to be coherent across the system.

- Systemic reform explicitly strives to support school-site efforts at redesigning teaching and learning in support of all students. Promulgation of 'top-down' and additive mandates is insufficient. Schools and districts must be supported and activated to transform teaching and learning as part of a coherent redesign.

Her ideas, in turn, point us to two questions: Can efforts to promote whole-school reform be synchronized with concurrent efforts at systemic reform? If so, what entities in addition to schools should become both targets and mechanisms for change?

SEAs are one possible answer to the last question. The roles of SEAs in relation to wholeschool reform are multiple, under-scrutinized, and perhaps even contradictory-as promoter, manager, initiator, intermediary, fiduciary agent, and more. Yet we know that both through the federal Obey-Porter Comprehensive School 
Reform (CSR) program and through other mechanisms (e.g., New Jersey's Abbott v. Burke litigation-see Erlichson 2005) that SEAs have substantive roles in how "the third wave of reform" (Desimone 2002, p. 434; Hamann 2005)—the comprehensive school reform movementplays out. This movement, which is both more popular and more criticized than ever before (Berends, et al., 2001; Sack, 2002; Viadero, 2001), asserts that whole schools should be units of change and that school change plans should articulate how all students and staff are to be participants in the multiple integrated steps for improvement. Keeping SEAs' multiple roles in mind, we need to explicitly examine if SEA involvement with whole-school change can be a mechanism for avoiding the disequilibrium problem, for having school improvement efforts co-occur and cohere with systemic ones. We also need to remember that since the early 1980s SEAs have seen declines in funding relative to expected responsibilities. As the Institute for Educational Leadership's (IEL's) Task Force on State Leadership proclaimed prior to the new mandates of No Child Left Behind, "Today, state education agencies are now almost too lean. Reduced budgets starting in the 1980s stripped them of their capacity to fill many vacancies, much less meet new demands" (IEL 2001:10).

The two cases that follow-one depicting Maine's efforts to promote high school reform one depicting Vermont's-both shed light on the interface between school change and system change. Both states' efforts acknowledge the particular difficulties of changing high schools and the startling resiliency of the comprehensive high school model championed fifty years ago by Harvard's President Bryant. (See Powell, et al. [1985].) Nonetheless, in the last decade both states have articulated new visions for high schools, visions that take as their starting point a presumption of whole school change. Yet as IEL's Task Force would predict, resource limitations and strategies to get around them, loom large in both stories.

Whole school change, or comprehensive school reform, is a deliberately chosen term. As Desimone notes, "In contrast to past efforts, comprehensive schoolwide reform focuses on improvement for entire schools rather than on particular populations of students within schools; and it is not limited to particular subjects, programs, or instructional methods" (2002:434). Even as they are systemic reform templates by their nature as state-developed and state-disseminated, both Maine's and Vermont's high school reform plans presume schools as the unit of change, recommending new school-wide practices. After a discussion of methodology and a quick review of how the two states' reform frameworks match and differ, this paper offers an early review of the reconciliation/juxtaposition of school reform and system reform in two states, concentrating on statelevel activity in regard to this interface.

As an introductory note of clarification, Datnow, et al. have defined scaling up "to refer to the deliberate expansion of an externally developed reform model, ... the transfer of external reform model to a number of settings" (2002:2). Their definition mostly applies here, but requires two caveats. Both Promising Futures (PF) and High Schools on the Move (HSOM) were originally crafted as frameworks for high school reform, not necessarily as models per se, though $P F$ in particular has subsequently been implemented as a reform model. Second, both of these high school reform frameworks were crafted by ad hoc, heterogeneous committees of educators and educational stakeholders from within the state to which the framework was to apply. Though neither framework has been mandated by either state, the frameworks' origins complicate a traditional understanding of what 'externally developed' means.

\section{The Ethnography of State-Level Work}

With rare exception (e.g., Lusi 1997, Hamann and Lane 2004), SEAs have not been sites for or topics of ethnography. This likely reflects the historic focus of the anthropology of education on classroom interaction and/or on how marginalized students fare, but ethnography is an apropros methodological frame for the studies depicted here because of its concurrent focus on sense-making and on depicting praxis-i.e., how ideas are converted into practice (Erickson 1984). With this study ultimately concerned with how and whether SEAs converted 
ephemeral single-site school improvement into something more enduring and systemic, understanding the problem diagnoses and understandings of state-level personnel and chronicling what they did are useful targets of inquiry.

Proponents of the nascent field of ethnography of educational policy (e.g., Levinson and Sutton 2001), note that this sub-field is new. So, by necessity, it borrows from other research genres. The research methods pursued here include the traditional source of ethnographic knowledge -participant observation-reconciled with other forms of data collection. I pursue Nader's (1972) injunction, updated recently by Eisenhart (2001), that data collection strategies should be multiple and as eclectic as necessary, with the question to be answered determining methodological particulars. Eisenhart notes that the geography of ethnographic observation sometimes needs to be pluralized (i.e., occur at multiple sites) and that policy document review and other less traditional forms of data collection and analysis can be appropriate. This approach is also consistent with recommended methods for case study data collection (Cresswell, 1998).

Cresswell (1998) argues that a defining element of a case study is its boundedness. This characteristic is true of both cases that follow; they reference particular programs (HSOM and $P F$ ), a finite time period (from origin through 2003), and discrete entities (two SEAs, plus partners). Consistent with Stake's (1995) description of an instrumental case study, both cases were selected for the way they could illustrate an issue: the adoption and conversion to praxis of educational policy at the SEA level. The selection of cases was purposeful. At the time this study began, no other states in the country had outlined voluntary frameworks for high school reform that, in each case, could double as templates for comprehensive school reform.

I know both cases well, having had peripheral applied roles in both. But I know the Maine case better. Most of the data from Maine come from fieldnotes collected as part of four years of technical assistance and applied research, including more than 70 days of accompanying Maine SEA personnel as they carried out "MidCourse Review" visits to PF/CSR high schools across the state. It includes notes from seven professional development institutes at which SEA officials convened grant-receiving high schools. It includes notes from observing more than sixty end-of-year portfolio presentations by $P F / C S R$ grant recipients to SEA personnel. Complementing this participant observation, I have also reviewed achievement test data, the Maine Department of Education's (MEDOE) requests-for-proposals (RFPs) disseminated to potential $P F / C S R$ applicants, and multiple approved "Rider A" agreements (described further in the case). I did the bulk of the on-site observation and fieldnote writing described above, but was also assisted by several colleagues, notably Brett Lane. (See Hamann and Lane [2002, 2004]; Hamann et al. [2001].) In addition to our research in Maine, my colleague and I have been lead authors of five formative evaluations of Maine's CSR implementation, which has included a crucial tie-in with $P F$ (Hamann 2004; Lane and Hamann 2000, 2001, 2002a, 2002b). Finally, I have been involved in two other efforts involving high schools in Maine, as a consultant to MEDOE's strategizing about how to expend federal Title II (professional development) funds and as the designated drafter of a case study about one Maine county's ongoing implementation of an acrossthe-content-areas adolescent literacy initiative (Hamann and Meltzer 2005).

I gathered the information shared here in Vermont by participating in 2003 on the task force charged with developing an implementation strategy for HSOM. I was the only nonVermonter on that task force. I attended the 2002 kick-off of HSOM (an event attended by more than a dozen high schools). I also gathered and examined multiple drafts of plans for a Vermont Public Education Partnership HSOM support center and multiple drafts of grant proposals, notably those seeking help from the Gates Foundation. Finally, I conducted several key informant interviews (of varying formality) including some with my colleague John Clarke, who was a key, Vermont-based, drafter of HSOM, and from 2001 to 2003 was co-lead with me on the Northeast and Islands Regional Educational Laboratory-funded Personalized Learning project. (See Clarke [2003] and Clarke et al. [2000].)i 
As a final methodological note, echoing Delgado-Gaitan (1990:3) I have consciously rendered the two cases here using the past tense (even though both $P F$ and HSOM were ongoing initiatives as I typed these words) because it would be misleading to have the audience of this document believe that what I observed was static and unchanging. Moreover, my projections about the apparent viability of both state's implementation is a point in time projection. Vermont's prospect of success is viewed skeptically in the document that follows, but that projection could easily prove inaccurate. In 2004, after my fieldwork had finished, members of Vermont's HSOM Task Force had redoubled efforts to obtain external funding to support a statewide implementation infrastructure (although apparently without immediate success). Perhaps that effort will succeed, meaning that the cautious conclusion from a comparison of the two states should claim no more than that through planning and serendipity Maine was able to mobilize and raise the prospect of systemic reform faster. As of this writing (in 2005), success or failure was still to be determined; writing in the past tense safeguards against inappropriately enduring characterizations.

\section{Establishing the Similarity Between Two States' High School Reform Frameworks}

In the mid-1990s educators on Maine's ad hoc Commission on Secondary Education began visiting high schools in Vermont to see personalized learning plans and other innovations in action. Thus, their 1998 report, $P F$, incorporated what they had learned from schools in their fellow northern New England state. In 2002, the Vermont High School Task Force, made public its success at learning from the experience of Maine. HSOM included $P F$ in its bibliography and the imprint of Maine's experience was readily visible in the twelve principles adopted as the core of Vermont's report. The key purpose of this segment of the paper is to establish that $P F$ and HSOM are substantively similar documents. Drawn up by different authors at slightly different times, they are not identical, but it is my assertion that they are not so different that, as templates for change, one is more likely to be viable than the other. HSOM offers as viable a vision and as relevant and tangible a set of proposed strategies as $P F$ and vice versa. If, in implementation, one appears to be more viable than the other (and that has been the case), it is because of differences in state-level implementation strategy (including resources) and various unexpected serendipitous factors (like the availability of federal high school reform monies).

Historically, Maine and Vermont have prioritized schooling, which is evidenced by their contemporary and historic high levels of literacy and by their status as two of the top three states in the nation in investing in education as measured by percentage of gross state product spent on education in 1997 (Education Week 2000). (West Virginia was the other.) Thus, perhaps it should not be surprising that, in the words of several high school-reform advocates at the National High School Alliance (personal communication), that Maine and Vermont "stand out" nationally for their SEA-level activism regarding high school reform.

Nor should it be surprising that the frameworks for reform adopted in both states include a substantive emphasis on democracy and the choice to engage with the recommended frameworks. Both Maine and Vermont have longstanding traditions favoring democratic processes and local control that have been applied to schooling governance as well as other institutions (Lusi 1997, Ruff 2000). Yet both states joined the nationwide move to academic standards in the early 1990s. Vermont's State Board of Education adopted the Common Core of Learning in 1993. Maine published a like-named document-The Common Core of Learning in 1990 and followed up in 1997 by the more explicit State of Maine Learning Results. Both states' high school reform frameworks were written, in part, as strategies to increase the number of Maine and Vermont high school students who were meeting their respective state standards. Figure 1 shows how the 15 core practices of $P F$ match up with twelve key principles of HSOM. Figure 2 repeats this idea in reverse, listing the Vermont principles and noting which practices they are like.

As both Figure 1 and Figure 2 illustrate, there is a substantial overlap between $P F$ and HSOM, with both describing the need for high schooling to be more personalized (i.e., students better known and respected) and coherent. 


\begin{tabular}{|c|c|}
\hline Maine's Promising Futures Core Practices & $\begin{array}{l}\text { Relevant HSOM } \\
\text { Principle(s) }\end{array}$ \\
\hline $\begin{array}{l}\text { Core practice 1: Every student is respected and valued by adults and by } \\
\text { fellow students. }\end{array}$ & 4 \\
\hline $\begin{array}{l}\text { Core practice 2: Every teacher tailors learning experiences to the learner's } \\
\text { needs, interests, and future goals. }\end{array}$ & $3,4,5$ \\
\hline $\begin{array}{l}\text { Core practice 3: Every teacher challenges learners both to master the } \\
\text { fundamentals of the discipline and to integrate skills and concepts across } \\
\text { the disciplines to address relevant issues and problems. }\end{array}$ & $1,5,8$ \\
\hline $\begin{array}{l}\text { Core practice 4: Every student learns in collaborative groups of students } \\
\text { with diverse learning styles, skills, ages, personal backgrounds, and } \\
\text { career goals. }\end{array}$ & \\
\hline $\begin{array}{l}\text { Core practice 5: Every student makes informed choices about education and } \\
\text { participation in school life and takes responsibility for the consequences } \\
\text { of those choices. }\end{array}$ & 1 \\
\hline $\begin{array}{l}\text { Core practice 6: Every student employs a personal learning plan to target } \\
\text { individual as well as common learning goals and to specify learning } \\
\text { activities that will lead to the attainment of those goals. }\end{array}$ & $3,4,5$ \\
\hline $\begin{array}{l}\text { Core practice 7: Every teacher makes learning standards, activities, and } \\
\text { assessment procedures known to students and parents and assures the } \\
\text { coherence among them. }\end{array}$ & 5,8 \\
\hline $\begin{array}{l}\text { Core practice } 8:^{*} \text { Every student who receives the secondary school diploma } \\
\text { has demonstrated, through performance exhibitions, knowledge and skills } \\
\text { at a level deemed by the school and by the state sufficient to begin adult life. }\end{array}$ & $1,2,6,8,10$ \\
\hline $\begin{array}{l}\text { Core practice 9: Students and teachers belong to teams that provide each } \\
\text { student continuous personal and academic attention and a supportive } \\
\text { environment for learning and growth. }\end{array}$ & 4 \\
\hline $\begin{array}{l}\text { Core practice 10: Learning governs the allocation of time, space, facilities, } \\
\text { and services. }\end{array}$ & 5 \\
\hline $\begin{array}{l}\text { Core practice 11: Every teacher has sufficient time and resources to learn, } \\
\text { to plan, and to confer with individual students, colleagues, and families. }\end{array}$ & 5 \\
\hline $\begin{array}{l}\text { Core practice 12: Every staff member understands adolescent learning and } \\
\text { developmental needs, possesses diverse instructional skills, and is a } \\
\text { constructive model for youth. }\end{array}$ & $3,4,7$ \\
\hline $\begin{array}{l}\text { Core practice 13: Every school has a comprehensive professional } \\
\text { development system in which every staff member has a professional } \\
\text { development plan to guide improvement. }\end{array}$ & 7,9 \\
\hline $\begin{array}{l}\text { Core practice 14: Staff, students, and parents are involved democratically } \\
\text { in significant decisions affecting student learning. }\end{array}$ & $1,4,9$ \\
\hline $\begin{array}{l}\text { Core practice 15: Active leadership by principals inspires and mobilizes } \\
\text { the staff, students, and parents to work toward the fulfillment of the } \\
\text { school's mission and, within it, their own learning and life goals. }\end{array}$ & $7,11,12$ \\
\hline \multicolumn{2}{|l|}{ Figure 1. Promising Futures' Core Practices and HSOM's Core Principles } \\
\hline
\end{tabular}




\begin{tabular}{|c|c|}
\hline High Schools on the Move Core Principals & Related PF Core Practices \\
\hline $\begin{array}{l}\text { Principle 1: Engaged Learners -Students are engaged learners who } \\
\text { are responsible for and actively involved in their own learning. }\end{array}$ & $3,5,8,14$ \\
\hline $\begin{array}{l}\text { Principle 2: Challenging Standards - Each student is expected to } \\
\text { demonstrate that he or she has met challenging standards based on } \\
\text { Vermont's Framework of Standards and Learning Opportunities or } \\
\text { national standards. }\end{array}$ & 8 \\
\hline $\begin{array}{l}\text { Principle 3: Multiple Pathways - High schools provide each student } \\
\text { with a variety of learning opportunities and multiple pathways to } \\
\text { meet graduation requirements. }\end{array}$ & $2,6,12$ \\
\hline $\begin{array}{l}\text { Principle 4: Personalized Learning - High schools create small, } \\
\text { personalized, and safe learning environments that provide students } \\
\text { with stable support from adults, caring connections to mentors, and } \\
\text { a sense of belonging. }\end{array}$ & $1,2,6,9,12,14$ \\
\hline $\begin{array}{l}\text { Principle 5: Flexible Structures - High school schedules and } \\
\text { organizations are flexible to allow time for varied instructional } \\
\text { activities and to provide an integrated learning experience. Learning } \\
\text { is the constant; time is the variable. }\end{array}$ & $2,3,6,7,10,11$ \\
\hline $\begin{array}{l}\text { Principle 6: Real-Life Experiences - Students learn about careers } \\
\text { and college opportunities through real-life experiences and adult } \\
\text { interaction, including work-based learning, service learning, career } \\
\text { exploration, job shadowing and career academies. }\end{array}$ & 8 \\
\hline $\begin{array}{l}\text { Principle 7: Instructional Leadership - Adults in the school use } \\
\text { research-based practices and effective administrative and } \\
\text { instructional strategies to support increased student performance. }\end{array}$ & $1,12,13,15$ \\
\hline $\begin{array}{l}\text { Principle 8: Alignment - Supported by research-based professional } \\
\text { development, high schools align their curricula, instruction and } \\
\text { assessment with Vermont's School Quality Standards. }\end{array}$ & $3,7,8$ \\
\hline $\begin{array}{l}\text { Principle 9: Shared Purpose - Every high school adopts and } \\
\text { publicizes a compelling vision and mission that uses a } \\
\text { results-oriented approach to promote continuous improvement. }\end{array}$ & 13,14 \\
\hline $\begin{array}{l}\text { Principle 10: Pre-K-16 Continuity - Every high school is a member } \\
\text { of a pre-K-16 education system and is a partner with middle schools, } \\
\text { colleges and postgraduation training programs to help students } \\
\text { make successful transitions. }\end{array}$ & 8 \\
\hline $\begin{array}{l}\text { Principle 11: Family Participation - Families are active participants } \\
\text { in their young adults' education and have varied opportunities to } \\
\text { volunteer, serve on decision-making groups, assist students in } \\
\text { setting learning goals, monitor results and support learning at home. }\end{array}$ & 15 \\
\hline $\begin{array}{l}\text { Principle 12: Community Partnerships - Every high school forms } \\
\text { active partnerships with families, community members, business } \\
\text { people, civic leaders and policy-makers to ensure fiscal support and } \\
\text { to expand student learning opportunities. }\end{array}$ & 15 \\
\hline
\end{tabular}


Both models describe changes in structures and practices and both depict roles for students, teachers, and administrators, though HSOM goes farther, by also acknowledging community and family engagement strategies and the need for alignment with middle schools and higher education. As a document, HSOM is also more explicit about the importance of meeting state standards, though that is less of a difference from $P F$ than might first be apparent, as in 2004 Maine formalized Core Practice \#8-the need to demonstrate mastery of school and state standards-as state policy. Moreover, when Maine first found a way to provide grant money to support $P F$ implementation (further discussed in the next session), the "Purpose" section at the beginning of that RFP explained:

[This] program provides funding to the secondary schools having the greatest need to substantially improve student achievement on the Maine Learning Results. CSRD funds are targeted for secondary schools to help them meet the vision and core recommendations made in the report Promising Futures by the Maine Commission on Secondary Education. Schools that receive CSRD funding will work to implement four core practices identified in Promising Futures as key to improving student achievement.

The only substantial recommended practice in $\mathrm{PF}$ that is not matched in HSOM is Core Practice \#4, which recommends heterogeneous grouping of students. Though the research base for this practice is solid (e.g., Oakes 1985), it is a consistently politically controversial topic (Oakes and Lipton 1999). The authors of HSOM may have decided that directly broaching this would be too controversial. For Maine high schools implementing $P F$ with the help of external grant monies, heterogeneous grouping has not been a required practice.

\section{Early Implementation}

In this segment, Maine's early experience crafting and implementing $P F$ and Vermont's early experience crafting and implementing HSOM are described. Maine has been implementing since 1998 and Vermont since 2002, so the Maine case is longer. In each case, around the time the respective framework was published, federal grant monies not initially explicitly intended to support a state high school reform framework were directed to do so. Maine subsequently built on this early opportunity, whereas in the face of several changes in commissioner Vermont's effort did not immediately grow in reach or depth.

\section{MAINE}

In 1998, MEDOE published PF. With the national economy flush and federal interest in whole school reform growing, the timing was serendipitous as a new coordinating entity for high school reform-the Center for Inquiry in Secondary Education (CISE)—had just been created within MEDOE and early planning for the federal Obey-Porter CSR program had just begun. When $P F$ was released, it was announced as an invitation for change. However, with the important exception of charging CISE with promoting it, few resources were initially available to support its implementation. But soon $P F$ and the Obey-Porter CSR program would be linked.

$P F$ had been drafted at the impetus of Maine's commissioner. According to his problem diagnosis-that Maine 4th graders dramatically outscored their peers from other states on the National Assessment of Educational Progress, that Maine 8th graders somewhat outscored their peers nationwide, but that Maine high school students were indistinguishable from the national average-Maine needed to prioritize its school improvement efforts at the high school level. The Maine Commission on Secondary Education responded by articulating six core principles, 15 core practices (see Figure 1), and a three-page list of typical high school activities that should be discontinued. In a very real sense, $P F$, authors crafted a process model for whole school change like many supported in the federal Obey-Porter CSR legislation. But, $P F$ was not initially labeled a school reform model. Unlike other models, it did not have a non-governmental model development and support infrastructure.

$P F$ was also consciously a local document, assembled primarily by educators at schools, district offices, MEDOE, and universities from across the state. In his letter at the beginning of $P F$, the Commissioner wrote: "The report of the 
Commission on Secondary Education represents a critical milestone in Maine education; for the first time in the State's history, a group consisting of some of our finest educators has undertaken a comprehensive review and analysis of the condition of our system of secondary education" (1998:iii, italics added).

In 1998, with enthusiasm for $P F$ high but next steps not immediately certain and with the coaxing of a member of the Commission on Secondary Education, MEDOE staff realized that federal CSR funds might be used as carrots to encourage Maine high schools' embrace of $P F$. That summer MEDOE administrators successfully requested federal waivers to restrict Maine's CSR competition to high schools, to attach parts of $P F$ to the request-for-proposals distributed to schools, and to deemphasize Title I status (but not need) as a criterion for making awards (because very few Maine high schools were Title I schools). Once the waivers were granted, Obey-Porter was no longer just a small new federal program with a lot of procedural details; instead, it was a means to realize a locally articulated high school reform agenda around which there had been much recent mobilization. In turn, $P F$ was no longer a recommended framework for change, it was the template around which school reform grant proposals had been crafted and through which particular strategies were to be followed. With CISE overseeing implementation of $P F$, it followed logically that CISE should oversee the PF-linked implementation of CSR.

Key implementation adaptations to Promising Futures in Year 1 of CSR:

CISE's original involvement with $P F / C S R$, however, was not much more than having the CSR Coordinator (whose half-time position in that role was federally supported) coordinate and oversee the initial grant competition that led to 11 high schools being selected for CSR grants. In April of 1999 after the list of the first PF/CSR awards had been publicized, Maine's half-time CSR coordinator naively attempted to alert MEDOE's finance division that the selected schools were ready to receive their first-year allocation. "Naïve" reflects her characterization of that request. To the surprise of the coordinator, the staff of MEDOE's finance division explained that they could not simply write a check and mail it. For any disbursement of greater than $\$ 25,000$, MEDOE required a detailed contract, also known as a 'Rider A,' between the recipient and MEDOE. Moreover, to receive funding in Year Two and Year Three, schools would need to submit adjusted Rider A contracts.

In May 1999, the CSR coordinator needed to tell the selected schools that they could not yet receive their money because they had not passed the state requirement-the Rider Athat were unaware of until that moment. The Rider A contracts required more substantive and short-term proof of implementation and outcomes than had the schools' PF/CSR applications, so schools had to revisit their applications and describe much more detailed methods of documenting implementation and outcomes than they had initially anticipated. During the summer of 1999, the CSR Coordinator worked with all of the schools on their contracts.

After offering a mea culpa regarding the Rider A contracts, in her early interaction with the first cohort of $P F / C S R$ schools the coordinator simultaneously indicated her seriousness and receptivity to suggestions regarding how to solve the Rider A dilemma. Rider A contracts were not an obstacle that could be sidestepped or resisted, but how to meet the Rider A requirement for careful documentation was an open topic for discussion and shared problem solving.

In September 1999, with each school aware that the dilemma of documenting Rider A compliance needed to be solved quickly and after each school had been solicited for input, the CSR coordinator decided that each CSR school would document their implementation in a school portfolio. Having made this determination, the coordinator subsequently found Victoria Bernhardt's (1994) The School Portfolio: A Comprehensive Framework for School Improvement and used that as a guide. At the end of each school year, each PF/CSR school would share its portfolio with the coordinator and would make a formal presentation of it to her and to whomever else the coordinator had recruited to review the presentation. 
Though continued Obey-Porter CSR funding was officially contingent on successful completion of the portfolio task, the portfolio review process was explicitly much more akin to formative evaluation than summative. The portfolio guidelines the coordinator subsequently created-a.k.a., "The Continuum of Evidence"gave schools straightforward guidelines and benchmarks around which to coordinate both their implementation and their portfolio drafting.

The coordinator promised that she would be available throughout the course of the year to answer questions about the portfolio development process or any other PF/CSR-related matter, a promise that she used several strategies to keep, including drafting and distributing "The Continuum of Evidence" and making "MidCourse Review" site visits to each school in March 2000. The "Continuum of Evidence" offered an eight-point guide for portfolio elements. This made explicit both what kind of information needed to be gathered for the portfolio and how it was to be arranged. School personnel could also see clearly the criteria or expectations within each category.

There are three reasons for telling this first-year of implementation in greater detail than what has occurred subsequently and in greater detail than the Vermont case includes. Three key strategies/habits of action were invented in this first year that were crucially relevant to the further dissemination of PF in Maine: (1) personalized, collegial, and frequent interaction between SEA and school personnel; (2) the complementing of the shared template of $P F$ with the similar tasks of Rider A and portfolio development; and (3) the growing lateral exchange of information between implementing sites, both direct and through SEA personnel as conduits (Hamann and Lane 2002, 2004).

A fourth trend also emerged in this first year: Those who had served on the PF-drafting Commission on Secondary Education took on multiple roles related to $P F / C S R$ implementation. Several commission members became school coaches (external advisors to grant implementing schools). Other commission members went on to work for CISE. This fourth trend increased the alignment between school- level efforts and policy efforts at further remove from the classroom.

Personalized Interaction, Shared Tasks, and the Lateral Exchange of Information

In the second year of Maine's PF/CSR implementation, the link to CISE became more important. Even though, formally, only one CISE staff person was designated as CSR Coordinator and supported (half-time) by federal CSR funds, additional CISE staff members became involved in PF/CSR schools supported by other resources. These SEA-based educators contributed as a team to the coordination of CSR implementation. As a CISE-based educator observed in May 2002, "If we had to revert to relying on the $5 \%$ [SEA-level Obey-Porter CSR] allocation, we'd only be doing compliance and checklist activities, no leading." Instead, the state's investment in CISE meant PF/CSR implementation was coordinated by a team, with the ratio of SEA-staff to implementing schools as low as 1:4. Site visits became more frequent and, as they learned about the challenges and successes of each site, SEA personnel became more informed and more adept at relating lessons from one site to another. In enacting this habit, it should be noted, the SEA staff from CISE consistently deployed a particular ethic: If they were recommending School A's promising practice to School B they were careful to name names, giving credit where credit was due. However, when the tales were cautionary (e.g., 'some schools have struggled with') the referent school was always kept anonymous.

This school-to-school sharing took three distinct forms, but in all instances was crucial to understanding how single-school change increasingly appeared to be systemic. As just suggested, SEA staff at CISE were a key conduit, responding during site visits and at portfolio presentations to school personnel's identification of struggles and challenges with ideas and recommendations gathered at other implementing schools. (They also offered similar support in e-mail and telephone communication.) SEA staff also encouraged direct school-to-school communication, a habit that emerged at several retreats where educators from the multiple implementation sites were able to meet each other and talk about their implementation, but 
that was then sustained by direct site visits (in which SEA staff were not directly involved). Since 1999, school's use of staff development days to send teachers for one-day visits to implementing schools to learn about aligning curriculum and assessment with standards or managing an advisory system or implementing a student-led conference process with parents all became more common. Less commonly, school board members and students would also participate on such visits. Usually, site visits were followed by academic department or school-wide debriefings.

The third vehicle of school-to-school communication was by way of school coaches. Though the document $P F$ was silent about any role for externally-based school coaches, some of the members of the commission that drafted it were university-affiliated professional developers. More importantly for this story, when Maine's CSR coordinator was first charged with reconciling $P F$ with the nine original requirements of the federal Obey-Porter CSR program, she determined that the best way to ensure that all funded schools complied with federal component \#7-the expectation that schools would contract for external technical assistance and support-was to require each applicant school to identify an externally-based coach. Since 1999, schools have contracted with coaches from three state universities, as well as with several who were independent. Like CISE staff, university-affiliated coaches learned from their colleagues' experiences of their colleagues and could use that learning to comment on struggles and successes that they had encountered elsewhere. In addition, to being 'story carriers' by virtue of where and how they worked, the coaches themselves become part of the capacity to make $P F$ a systemic reform by aligning at least portions of higher education with high school change efforts. When Maine received funding to expand the reach of $P F$ with the assistance of a \$10 million grant from the Gates Foundation (discussed more below), schools that sought Gates funding were also required to identify an external coach. Thus this component of school-to-school information transfer and expertise development was further institutionalized.
The accessibility, candor, and collaborative leadership style of CISE staff (and of coaches)— their personalization of the policy processwere integral for the relative success of implementation achieved at Maine PF/CSR high schools (Hamann and Lane 2002, 2004). This success is consistent with Wang, Haertel, and Walberg's (1993:279) finding that education policy changes made at a distance from the classroom only change classroom practice and student achievement to the extent they affect the more proximal, localized, and customized policies that actually shape procedures in specific classrooms. (See also Clarke, et al. [2000].) SEA staff played a bridging role, assuring that the policies of $P F$ and Obey-Porter were comprehensible and compelling to school-based educators and thus that these policies became sources of their school and classroom policymaking and enactment. The stability of CISE staffing mattered, as the interpersonal relationships cultivated between personnel at the MEDOE and at schools could continue to deepen and become stronger vehicles of support and innovation.

Three More Ways of Making Promising Futures Systemic

As of 2004, the implementation of $P F$ by way of CSR funding had been undertaken by 33 of Maine's 157 public high schools. This effort drew national interest. In 2003, the Gates Foundation contributed \$10 million to Maine's Mitchell Institute to support additional high schools' implementation of $P F$. This boosted the number of schools that wrote grant proposals using $P F$ as a template, as the Gates grant was distributed to schools through a competitive process. Through CSR or Gates, more than fifty Maine high schools received at least one form of funding to implement $P F$. If one also counts unsuccessful CSR and Gates applicants, then more than half of Maine high schools articulated plans for $P F$ implementation by the end of 2003. To oversee implementation of the Gates grant, the Mitchell Institute hired the former cochair of the PF-drafting Maine Commission on Secondary Education who subsequently had worked at CISE. Such a strategic hire further institutionalized $P F$ as Maine's vehicle for high school change. 
In 2003, Maine also adopted a new law, called Chapter 127, which formalized $P F$ core practice \#8 into official state policy. That law required that, starting with the high school graduating Class of 2008, all seniors would have to demonstrate proficiency on the Maine Learning Results to receive a diploma. Unlike in Texas, Massachusetts, or other states with high stakes tests as a graduation requirement, Maine left it to the discretion of school districts to determine the way(s) students could exhibit proficiency, but mastery of standards was now formalized as a graduation criteria for all. At the end of 2003, MEDOE officials, some with CISE, some not, also began a discussion of how to use federal Title II professional development funding to target high school educators who needed further skill acquisition to gain the capacity to realize the principles and engage in the practices articulated in $P F$. While as of this writing that conversation had not been fully converted yet into formal policy or an RFP, it is mentioned here as yet further demonstration of an effort to direct resources towards the realization of $P F$.

Although the important theme of this segment has been to clarify how state-level activities have improved the prospects for $P F$ to be a vehicle of statewide high school reform, readers may want to know to what consequence in terms of outcomes all this mobilizing has accomplished. In 2002, using Cuban's (1998) five perhaps unorthodox criteria for measuring the success of an educational policy-effectiveness, popularity, fidelity, adaptability, and longevity-I labeled $P F$ implementation a multi-dimensional success (Hamann and Lane 2002). If anything, that characterization seemed even more applicable at the end of 2003, with one possible caveat.

According to effectiveness criteria like Maine Education Assessment scores, graduation rates, and grade point averages, implementing schools did not have a consistently favorable record. Nonetheless, in aggregate, they fared modestly better than Maine high schools not receiving financial support related to $P F$ (Hamann 2004). Perhaps as policy implementation scholar Milbrey McLaughlin (1987) would suggest, it was too early to look at this kind of measure. In 2002 an educator at one of the first
CSR/PF high schools explained that appropriate measurement of his school's successes or struggles could only begin with the Class of 2004 as that class was the first at his school to experience changed practices in each of their years at high school. By that standard and excluding a tiny rural school whose sample size of test takers is too small for meaningful year-toyear comparison, of Maine's other ten first $P F / C S R$ schools, nine showed improvement in writing, measured by percentage of students meeting or exceeding the standard in that topic. Seven showed improvement in science (and one matched its baseline score). But only three improved in math and only one improved in reading (while one matched its baseline). Each of these schools had begun implementation in 1999-2000 and all but two had changed principals since then.

\section{VERMONT}

If NAEP scores were the precipitating factor that compelled Maine's Commissioner to create the Maine Commission on Secondary Education that subsequently drafted $P F$, the high rate of status dropouts in Vermont (i.e., those without diplomas who were not in school) was the leading factor that led to the creation of Vermont's High School Task Force. However, as Figure 2 (p. 7) illustrates, mastery of standards emerged as an important priority for the Vermont task force. As in Maine, the task force drew together some of the state's leading experts on high schools, including teachers, principals, district and VTDOE personnel, and university-affiliated scholars and professional developers. Unlike in Maine, Vermont also included two students, a legislator, and two business representatives on the task force.

Vermont's timing for the publication of HSOM was less propitious than Maine's earlier effort. The Vermont High School Task Force, which was created in 1999 by the State Board of Education to examine the status of the state's secondary education system, completed its initial mission in 2002 with the publication of HSOM. The document was published in August of that year and in early December there was a formal one-day kick-off, which was attended by personnel from more than a fifth of the state's high schools, several of which had brought stu- 
dents. The kick-off was a day of great enthusiasm and possibility (I offer that as a first-hand impression, I attended), but no new resources to support HSOM implementation were announced and, while follow-up was promised, the details of that follow-up were only loosely sketched.

At the state-level, the most substantive nearterm follow-up was the creation of the HSOM Design Team. Calling this a new group is misleading because it was mostly composed of high school reformers who had been collaborating for several years on the Task Force and then on the December 2002 kick-off. However, this group did not have quite the same composition as those that had proceeded (several Task Force members were not participants and, supported by Northeast and Islands Regional Educational Laboratory contract, I joined the group at the beginning of 2003). Also its charge had been updated, instead of drafting the template for reform or plotting its state-wide release, the design team's main charge was to figure out the next steps that had only been hinted at during the December kick-off. The Design Team included representatives from the Vermont Department of Education, the University of Vermont, the Vermont State College system, some district administrators, and a professional developer who had retired from the University of Vermont's teacher education faculty.

At almost monthly meetings, the Design Team engaged in three primary tasks: articulating a design for a Vermont Public Education Partnership (VPEP) Center for HSOM, drafting funding proposals that could be used to support both the center and schools willing to be pilot implementers of HSOM, and strategizing about ways to gain political support for design ideas and grant proposals. Several factors complicated these three charges, most notably in the fall of 2002 the Commissioner of Education whose enthusiastic letter of support was at the beginning of HSOM left his job and the state to take a position with the Gates Foundation's high school reform efforts.

While there was initial optimism that this would improve the likelihood of obtaining Gates Foundation support for next steps, the opposite actually seemed to be true. This was not because the former commissioner did not retain a favorable disposition towards Vermont and the framework, but rather because it was actually harder for him as a new foundation employee to support his old colleagues than practically anyone else. Gates support to Vermont would look like favoritism (because of the personal ties) unless the rationale for funding was airtight. Gates Foundation support at a time when the VTDOE was being led by an interim commissioner was risky: Who could promise that the next permanent commissioner would want to endorse HSOM? A change in the Governor's office (with a Republican replacing Howard Dean who had met his term limit) also clouded the future regarding long-term in-state support of HSOM.

Through 2003 the Design Team continually refined proposals to be submitted to the Gates Foundation and it brainstormed about potential other sources of funding, but no obvious additional options emerged. The tight state budget (exacerbated by a reduced flow in federal aid to states as well as by the national economic slowdown) reduced the even limited prospect that the interim commissioner would be willing to reallocate department resources to commit more than the existing time of a handful of VTDOE employees to high school improvement (including but not limited to HSOM). The interim commissioner did profess his support for HSOM (which, having heard it in person, I found to be sincere) and he did contribute ideas regarding the tactics of obtaining support from the state legislator and school board, but he dared not do anything bold and unorthodox like creating a new CISE-like entity. Nor did he find internal or external funds that could be allocated to HSOM. As a consequence, the gap in time between HSOM's kick-off and much formal state-level development (as opposed to planning) grew wider.

According to a member of the design team who worked most closely with high schools, as this stretch of inaction grew the schools that had seemed willing to be, in his words, "lead dogs" grew increasingly skeptical that more substantive support for HSOM would be forthcoming. The opportunity precipitated by the kick-off was disappearing, even though in October 
2003, the Vermont State Board of Education adopted a resolution in support of HSOM, endorsing it vision and supporting its 12 principles as a promising approach to accomplishing significant and lasting improvement in Vermont's secondary schools.

Model vs. Framework

HSOM also faced another obstacle to its prospective emergence as the centerpiece of a systemic reform initiative. In an introductory letter to HSOM that was dated August 2002, the Chair of Vermont's State Board of Education had written, "The work of the Task Force will be significant locally in Vermont, but it also has been recognized and rewarded nationally through the award of one of five $\$ 1$ million demonstration grants for high school reform." While the Chair of the Board may have been technically accurate in noting that the task force had been a reason that in October 2001 Vermont was one of three states to land a federal High School Reform State Grant, he did not include in his reference that the award was soon all devoted to five high schools' creation of career academies.ii Nor did he reference several Vermont high schools' adoption of High Schools That Work, a promising model for school reform developed by the Southern Regional Education Board. Both the career academy effort and the partnerships with High Schools That Work were compatible with $H S O M$, but they de-centered HSOM as the beginning point guide and rationale for their change efforts. Funded efforts at various schools did go forward but not under a larger framework promising systemic instead of scattered reform.

Attentive readers might ask whether career academy efforts and partnerships with High Schools That Work suggest that systemic high school reform was in the offing in Vermont, just with a different starting template. Perhaps that could have occurred, but the Vermont Task Force had explicitly avoided endorsing any particular externally developed model, meaning that, though not quite either/or, the career academies and the external model were counterpoised with the framework. HSOM lacked resources and a strategy of implementation (despite the design team's efforts to find/gener- ate both) and competed with other high school change currents that were also in play in the state.

\section{Resources, Alignment, and Designation of Responsibility Matter}

It is worth repeating the crucial caveat of this paper. Though Vermont is being identified here as not yet (as of 2005) having much success leveraging $H S O M$ as a statewide reform initiative, that may ultimately be the outcome.iii Indeed, given the experience and talent of those promoting Vermont's efforts and given the similarities between HSOM and Maine's $P F$, which has been viably leveraged to be a statewide initiative, there are grounds for optimism about HSOM's future. Nonetheless, as of this writing that promise was still more conjectural than realized and that is where this analysis needs to start. What did Maine do that Vermont did not? Was Maine just serendipitous launching $P F$ in 1998 at a time of relative prosperity and just as federal Obey-Porter CSR monies were becoming available; advantages not present in 2002? Was Vermont unlucky that its former commissioner of education, who had blessed HSOM, had gone on to the Gates Foundation making the odds of Vermont getting foundation support that much harder because of the former commissioner not wanting to appear to be rewarding old friends and co-workers?

Five key differences seem to distinguish Maine's efforts from Vermont's, none of which have much to do with the actual content of the frameworks developed in each site, nor with the frameworks' development processes. First and foremost, Maine had consistent leadership from its commissioner supporting $P F$ through the drafting and initial implementation phases. When, in 2003 Maine's long-serving commissioner did finally leave that post, his replacement agreed quickly to embrace $P F$ (an embrace made politically easier by the recent acquisition of Gates Foundation support). During the same period, Vermont endured several turnovers at the commissioner level, the most consequential one being the departure to the Gates Foundation of the commissioner who had welcomed HSOM's publication.

Second, Maine created a vehicle within the SEA-i.e., CISE-that became a natural home 
for championing $P F$. Indeed, promoting $P F$ was CISE's formal charge (Hamann and Lane 2002). Though several VTDOE staff devoted substantial hours and energy to the development and promotion of $H S O M$, their job descriptions predated that document's drafting and ultimately encompassed more than just the state's new framework. Similarly, the involved district administrators and University of Vermont and Vermont State College faculty also devoted a lot of time and intellectual energy to both HSOM's creation and to the design team that was to figure out the next steps of implementation. But HSOM was not a core responsibility for any of them (nor for me). If HSOM failed to be broadly embraced, none would be out of work.

Third, Maine's successful linkage of $P F$ to its dissemination of CSR funds meant very early after $P F$ " kick-off there was a list of 11 schools that were on the record as embracing the framework. $P F$ existed not just as a collection of ideas captured in a published document, it existed as funded practice at multiple sites. Starting with this first cohort, expertise about how to implement $P F$ various core practices grew, both at the practitioner level and at the management level (meaning among principals, school coaches, and SEA personnel). When Maine's CSR funding increased so did the number of $P F / C S R$ schools, to 22 in 2001, to 33 in 2002, and to more than fifty once the Gates funding was distributed. In contrast, there were no quickly recognizable HSOM schools in Vermont (though several reportedly were at least initially willing to take on that mantle).

Both Maine and Vermont faced the resource limitations that all SEAs have recently negotiated (IEL 2001), although because of changes in the national economy MEDOE was likely less pressed in 1998 than were the state-level strategists in Vermont in 2002. As a fourth difference in the two launches, however, Maine was successful at directing external resources to $P F$ implementation (CSR funds, Gates monies, and possibly Title II revenue). Vermont's best opportunity to try such redirection was chronologically a bit off, with the federal 2001 high school change grant coming out enough ahead of HSOM, that it got 'branded' differently, supporting career academies rather than the state's framework which was publicly launched months later. Having already launched CSR in Vermont back in 1998 without focusing it per se on high schools, imitating Maine's strategy with this federal revenue source would have meant disqualifying types of schools (elementary and middle schools) that had become accustomed to the prospect of applying for such funding.

Finally, and most relevant to consideration of what differentiates single-school and ephemeral change from that which is more systemic and enduring, after six years of $P F$ implementation Maine appeared to still be succeeding at stimulating and aligning change efforts at the different tiers of the education (i.e., in the classroom, at the school level, and at the SEA, and external professional development tiers). Though Vermont too had representatives from multiple tiers on the task force and slightly fewer on the subsequent design team, fifteen months into its implementation it did not have equivalents of CISE staff at the SEA level, of $P F$-oriented school coaches as professional developers, and bands of networked implementers working at a critical mass of school sites. Nor could Vermont point to new state policies related to HSOM, like Maine could as a result of $P F$ (e.g., Maine's new requirement for students in the high school class of 2008 that they would only receive diplomas if they had demonstrated mastery of standards-a direct tie-in Core Practice \#8 of $P F)$.

Ultimately it matters to see whether Maine can change high school students' school outcomes and whether new practices like graduation by exhibiting mastery, standards-aligned assessments, personalized learning plans, and student-led conferences with faculty advisors and parents endure. The prospects are promising. As of this writing (in 2005), Maine high schools there did not want to stick out, that wanted to be middle of the road, increasingly needed to be conversant with $P F$ and to consider its recommended practices. Those schools that were not doing so increasingly appeared anachronistic and recalcitrant. In short, Maine had changed the default for what high schools should be. Despite its compelling vision for different high schools, Vermont had not yet leveraged such a movement. 
i I realize that it is common practice in a paper such as this to not name a key informant. However, because of the spirit of this reference-acknowledging a dedicated school reformer and researcher who has substantively added to my knowledge of high school reform-it seems more appropriate to name a name and offer credit where it is due, than to obscure the identity. Of course if I have misunderstood what John Clarke has tried to help me understand, then the error is mine, not his.

ii See http://www.ed.gov/programs/hsreformgrant/ awards.html (accessed May 31, 2005) for more on this award.

iii An announcement posted on Feb. 20, 2004 on the Vermont Department of Education's web site (http://www.state.vt.us/edu/new/html/pgm_his.html) did announce that the department was looking for two applicant schools to implement HSOM concurrent with High Schools That Work (which is wholeschool reform model that was developed by the Southern Regional Education Board in 1987 that has been implemented in several Vermont high schools). Drafters of HSOM have been emphatic that their document does not recommend a particular externally-developed reform model, but they do not contest their document's compatibility with several high school reform designs

\section{References}

Berends, Mark, S. N. Kirby, S. Naftel, and C. J.McKelvey 2001 Implementation and Performance in New

American Schools: Three Years into Scale-up.

Washington, DC: Rand.

Bernhardt, Victoria L.

1994 The School Portfolio: A Comprehensive

Framework for School Improvement (2nd edition).

Larchmont, NY: Eye on Education.

Boyer, Ernest

1983 High School: A Report on Secondary Education

in America. New York: Harper \& Row

Campbell, Jay R., Catherine M. Hombo, and John

Mazzeo

2000 NAEP 1999 Trends in Academic Progress: Three

Decades of Student Performance. Washington, DC:

U.S. Department of Education, Office of

Educational Research and Improvement.

Clarke, John

2003 Growing High School Reform: Systemic Change

as Organic Adaptation. In Personalized Learning:

Preparing High School Students to Create Their

Futures. Joseph DiMartino, John Clarke, and

Denise Wolk, Eds. Pp. 309-318. Lanham, MD:

Scarecrow.

Clarke, John, Janet Bossange, Clint Erb, David Gibson,

Brian Nelligan, Carol Spencer, and Mary Sullivan 2000 Dynamics of Change in High School Teaching:

A Study of Innovation in Five Vermont

Professional Development Schools. Providence, RI:

The Education Alliance at Brown.

Coburn, Cynthia

2003 Rethinking Scale: Moving Beyond Numbers to

Deep and Lasting Change. Educational Researcher 32(6): 3-12.

Cresswell, John

1998 Qualitative Inquiry and Research Design.

Thousand Oaks, CA: Sage.
Cuban, Larry

1998 How Schools Change Reforms: Redefining Reform Success and Failure. Teachers College Record 99: 453-477.

Datnow, Amanda, Lea Hubbard, and Hugh Mehan 2002 Extending Education Reform: From One School to Many. London: RoutledgeFarmer.

Delgado-Gaitan, Concha

1990 Literacy for Empowerment: The Role of Parents in Children's Education. New York: The Falmer Press.

Desimone, Laura

2002 How Can Comprehensive School Reform

Models Be Successfully Implemented? Review of Educational Research 72(3): 433-479.

Education Week

2000 Quality Counts 2000: Who Should Teach? Education Week 19(Jan. 13).

Eisenhart, Margaret A., 2001 Changing Conceptions of Culture and Ethnographic Methodology: Recent Thematic Shifts and Their Implications for Research on Teaching. In The Handbook of Research on Teaching, 4th edition. V. Richardson, Ed. Pp. 209225. Washington, DC: American Educational Research Association.

Erickson, Frederick

1984 [1973] What Makes School Ethnography 'Ethnographic'? Anthropology \& Education Quarterly 15(1):51-66.

Erlichson, Bari Anhalt

2005 Comprehensive School Reform in New Jersey: Waxing and Waning Support for Model Implementation. JESPAR 10(1): 11-32.

Fink, Dean

2000 Good Schools/Real Schools: Why School Reform Doesn't Last. New York: Teachers College Press.

Edmund T. Hamann

2004 Maine Comprehensive School Reform Demonstration Program: Year Four Evaluation Report. Providence, RI: Education Alliance at Brown University.

Hamann, Edmund T., Ed.

2005 The Roles and Possible Roles of State Departments of Education in Comprehensive School Reform. JESPAR 10(1).

Hamann, Edmund T. and Brett Lane 2002 We're From the State and We're Here to Help: State-Level Innovations in Support of High School Improvement. Paper presented at the American Educational Research Association annual meeting, New Orleans, LA

2004 The Roles of State Departments of Education as Policy Intermediaries: Two Cases. Educational Policy 18(3): 426-455.

Hamann, Edmund T., Brett Lane, and Matthew Hudak 2001 CSRD Roll-out in Maine: Lessons from a Statewide Case Study. Providence, RI: Northeast and Islands Regional Educational Laboratory at Brown University. Accessed 2/7/05 at: http://www.allianc.brown.edu/pubs/csrd/ME CSR D rpt.pdf 
Hamann, Edmund T. and Julie Meltzer 2005 Multi-Party Mobilization for Adolescent Literacy: A Rural Ethnography of Policy Development and Collaboration. Paper presented at the Annual Meeting of the American Educational Research Association, Montreal, April 13.

Institute for Educational Leadership

2001 Leadership for Student Learning: Recognizing the State's Role in Public Education. Washington, DC: Author.

Lane, Brett and Edmund T. Hamann 2000 Maine Comprehensive School Reform Demonstration program: Year One Evaluation Report. Providence, RI: Northeast and Islands Regional Educational Laboratory at Brown University.

2001 Maine Comprehensive School Reform Demonstration Program: Year Two evaluation report. Providence, RI: Education Alliance at Brown University.

2002a Maine Comprehensive School Reform Demonstration Program: Cohort II - Year One Evaluation Report. Providence, RI: Education Alliance at Brown University.

2002b Maine Comprehensive School Reform Demonstration Program: Cohort I - Year Three Evaluation Report. Providence, RI: Education Alliance at Brown University.

Lee, Valerie

2001 Restructuring High Schools for Equity and Excellence: What Works. New York: Teachers College Press.

Levinson, Bradley and Margaret Sutton 2001 Introduction: Policy as/in Practice-A

Sociocultural Approach to the Study of

Educational Policy. In Policy as Practice: Toward a Comparative Sociocultural Analysis of Educational Policy. Margaret Sutton and Bradley Levinson, Eds. Pp. 1-22. Westport, CT: Ablex.

Lightfoot, Sarah Lawrence

1983 The Good High School. New York: Basic Books.

Lusi, Susan. F.

1997 The Role of State Departments of Education in Complex School Reform. New York: Teachers College Press.

Maine Commission on Secondary Education

1998 Promising Futures: A Call to Improve Learning for Maine's Secondary Students. Augusta, ME: MEDOE.

McLaughlin, Milbrey. W.

1987 Learning from Experience: Lessons from Policy Implementation. Educational Evaluation and Policy Analysis, 9, 171-178.

McQuillan, Patrick

1998 Educational Opportunity in an Urban American High School: A Cultural Analysis. Albany: State University of New York Press.

Muncey, Donna and Patrick McQuillan

1996 Reform and Resistance in Schools and Classrooms: An Ethnographic View of the Coalition of Essential Schools. New Haven, CT: Yale University Press.

Murphy, Joseph and Amanda Datnow, Eds.

2003 Leadership Lessons from Comprehensive School Reforms. Thousand Oaks, CA: Corwin Press.
Nader, Laura

1972 Up the Anthropologist-Perspectives Gained from Studying Up. In Reinventing Anthropology. Dell Hymes, Ed. Pp. 284-311. New York: Pantheon Books.

Oakes, Jeannie

1985 Keeping Track: How Schools Structure Inequality. New Haven, CT: Yale University Press.

Oakes, Jeannie and Martin Lipton

1999 Access to Knowledge: Challenging the Techniques, Norms, and Politics of Schooling. In The Beat of a Different Drummer: Essays on Educational Renewal in Honor of John Goodlad. Kenneth A. Sirotnik and Roger Soder, eds. Pp. 131150. New York: Peter Lang.

Powell, Arthur G., Eleanor Farrar, and David K. Cohen 1985 The Shopping Mall High School: Winners and Losers in the Educational Marketplace. Boston: Houghton Mifflin.

Ruff, David, Debra Smith, and Lynne Miller

2000 The View From Maine: Developing LearnerCentered Accountability in a Local Control State. In Accountability, Assessment, and Teacher Commitment: Lessons from Kentucky's Reform Efforts. Betty Lou Whitford and Ken Jones, eds. Pp. 163-178. Albany: State University of New York Press.

Sack, Joetta

2002 Experts Debate Effect of Whole-school Reform. Education Week(Jan. 30): 6.

Sarason, Seymour B.

1990 The Predictable Failure of Educational Reform: Can We Change Course Before It Is Too Late? San Francisco: Jossey-Bass.

Sizer, Theodore

1984 Horace's Compromise: The Dilemma of the American High School. Boston, MA: Houghton Mifflin

1992 Horace's School: Redesigning the American High School. Boston, MA: Houghton Mifflin

1996 Horace's Hope: What Works for the American High School. Boston, MA: Houghton Mifflin

Stake, Robert

1995 The Art of Case Study Research. Thousand Oaks, CA: Sage.

Vermont High School Task Force

2002 High Schools on the Move: Renewing Vermont's Commitment to Quality Secondary Education. Montpelier: Vermont Department of Education.

Viadero, Debra

2001 Whole-school Projects Show Mixed Results. Education Week (Nov 7):1, 24-25.

Wang, Margaret, Geneva D. Haertel, and Herbert

Walberg

1993 Toward a Knowledge Base for School Learning. Review of Educational Research 63(3):249-294.

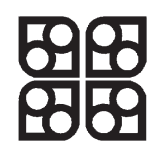

